FisiPublik : Jurnal IImu Sosial dan Politik

https://journal.uwgm.ac.id/index.php/fisipublik

P-ISSN: 2528-2689; E-ISSN: 2540-9751

Vol 03 No 02 November 2018,

\title{
Analisis Promosi Terbuka Jabatan Pimpinan Tinggi Pratama Di Kabupaten Pekalongan Tahun 2017
}

\author{
Dewi Mahanani ${ }^{1}$, Muhammad Eko Atmojo ${ }^{2}$ \\ 12Program Studi Ilmu Pemerintahan, Fakultas Ilmu Sosial dan Ilmu Politik, Universitas \\ Muhammadiyah Yogyakarta \\ Email: dewimahananiii@yahoo.com, atmojoeko91@gmail.com
}

\begin{abstract}
Abstrak
Sumber Daya Manusia (SDM) merupakan salah satu hal yang cukup penting karena SDM yang nantinya akan melaksanakan dan menyelesaikan beberapa hal terkait dengan pemerintahan. Dalam pelaksanaan itu sendiri tentu perlu adanya SDM yang profesional dan berkompeten agar dapat menyelesaikan tugasnya dengan baik dan berintegritas. Undang-Undang No 5 Tahun 2014 tentang Aparatur Sipil Negara menjelaskan manajemen Aparatur Sipil Negara untuk mendapatkan pegawai yang profesional, dalam hal memenuhi apa yang sudah diatur di dalam peraturan tersebut maka Pemerintah Kabupaten Pekalongan dalam hal pengisian kekosongan Jabatan Pimpinan Tinggi Pratama (JPT) dilakukan dengan promosi terbuka. Metode yang dilakukan Pemerintah dalam hal ini yaitu melalui seleksi administrasi, assesment center, seleksi bidang yang terdiri dari uji gagasan tertulis dan wawancara. Dengan adanya penjelasan mengenai sistem merit dan juga adanya promosi terbuka yang dilaksanakan, Pemerintah berharap adanya kesesuaian penempatan jabatan berdasarkan keahlian yang dimiliki dari ASN itu sendiri sesuai dengan kompetensi yang dilakukan.
\end{abstract}

Kata Kunci: Promosi Terbuka, Jabatan Pimpinan Tinggi Pratama, dan Assesment Center 
FisiPublik : Jurnal IImu Sosial dan Politik

https://journal.uwgm.ac.id/index.php/fisipublik

P-ISSN: 2528-2689; E-ISSN: 2540-9751

Vol 03 No 02 November 2018,

\title{
Analysis promotion open office Leaders High Pratama in Pekalongan Regency 2017
}

\begin{abstract}
Human resources (SDM) is one pretty thing important because resources will be implemented and finish some things regarding government. The implementation of itself certainly needs to the existence of SDM in which both professionals and competent to solve a good teaching process and integrity. The act no 52014 about years of state civil apparatus said management of state civil apparatus to get employees, professional, In terms of responding to what was fixed in the regulation is the government of Pekalongan district in terms of charging to the vacancy of the high leaders Pratama (JPT) should be conducted by the promotion open. A method by the government, in this case, is through administration selection, assessment center, selection fields are composed of the written ideas and interview. With the explanation on the system of merit and any promotion open, carried out the government hoped the placement office based on the skills possessed of itself following competence by.
\end{abstract}

Keywords: Open, Promotion the Post of High Pratama, Led and Assessment Center 
FisiPublik : Jurnal IImu Sosial dan Politik

https://journal.uwgm.ac.id/index.php/fisipublik

P-ISSN: 2528-2689; E-ISSN: 2540-9751

Vol 03 No 02 November 2018,

\section{Pendahuluan}

Untuk mencapai kesuksesan di dalam organisasi baik organisasi pemerintah maupun organisasi swasta kita membutuhkan Sumber Daya Manusia (SDM) yang dapat memiliki daya pikir yang cukup kuat. Ketika SDM itu memiliki daya pikir yang cukup baik maka akan menghasilkan pemikiran-pemikiran yang akan menciptakan sebuah perencanaan untuk mencapai tujuan dari organisasi tersebut. Di beberapa organisasi pemerintah, pengembangan dan meningkatkan SDM biasanya dilakukan dengan mengikutsertakan SDM untuk mengikuti pelatihan yang berhubungan dengan jabatan tugasnya agar dapat meningkatkan kemampuan dari individu itu sendiri.

Dalam mencapai tujuan dari organisasi itu sendiri juga perlu adanya penempatan yang sesuai bagi SDM untuk menduduki jabatan tertentu, dimana ketika kemampuan dan keahlian SDM itu sendiri tidak sesuai dengan jabatan yang dimiliki tentu akan memberikan dampak yang cukup besar dalam pengelolaan organisasi tersebut. Undang-Undang Nomor 5 Tahun 2014 menjelaskan "bahwa pengangkatan PNS dalam jabatan tertentu ditentukan berdasarkan perbandingan objektif antara kompetensi, kualifikasi dan persyaratan yang dibutuhkan oleh jabatan dengan kompetensi, kualifikasi dan persyaratan yang dimiliki oleh pegawai.”

Tahap-tahap yang perlu dilakukan untuk dapat membandingkan tiga perbandingan objektif diatas yaitu dapat dilakukan ketika proses rekrutmen berjalan. Rekrutmen merupakan salah satu cara untuk dapat mengisi kekosongan formasi yang ada di instansi pemerintah ketika kepala daerah tersebut tidak melakukan mutasi atau rotasi jabatan, selain itu juga untuk mengetahui tingkat kompetensi dari pejabat dapat diketahui pada proses rekrutmen yang berjalan. Pada proses rekrutmen beberapa tahapan yang akan dilakukan menurut Nasution (2013) yaitu memberikan pengumuman dimana pengumuman dalam hal ini dilakukan agar ASN dapat mengetahui bahwa diadakan proses promosi, selain itu juga tahap mekanisme seleksi dimana tahap tersebut terdiri dari seleksi administrasi, seleksi manajerial dan seleksi bidang dan yang terakhir yaitu pemberitahuan oleh panitia seleksi hasil dari setiap tahapan seleksi.

Dari hasil setiap proses rekrutmen itulah yang nantinya akan terlihat apakah pegawai yang lolos kedalam beberapa tahap tersebut sudah ditempatkan sesuai dengan keahlian yang dimilikinya. Menurut Atmojo (2016) menjelaskan bahwa promosi jabatan struktural struktural 
FisiPublik : Jurnal IImu Sosial dan Politik

https://journal.uwgm.ac.id/index.php/fisipublik

P-ISSN: 2528-2689; E-ISSN: 2540-9751

Vol 03 No 02 November 2018,

eselon II harus berdasarkan dengan kompetensi agar dalam pelaksanaan tata pemerintahan dan menjalankan tugasnya sebagai pegawai negeri sipil bisa dilakukan dengan efektif dan efisien.

Undang-Undang No 5 Tahun 2014 tentang Aparatus Sipil Negara (ASN) menjelaskan bahwa "manajemen ASN adalah pengelolaan ASN dimana untuk menghasilkan pegawai ASN yang profesional, memiliki nilaidasar, etika profesi, bebas dari intervensi politik dan juga bersih daripraktik korupsi, kolusi dan nepotisme." Penjelasan yang ada di dalam Undang-Undang tersebut diharapkan dapat dijadikan acuan dalam tatanan di sektor birokrasi agar setiap pegawai memiliki integritas agar tidak mengganggu pekerjaannya dalam melayani masyarakat dan melakukan tindakan yang melanggar hukum selain itu didalam menjalankan tugas pegawai harus memperhatikan peraturan yang sudah diatur didalam Undang-Undang No 5 Tahun 2014 tersebut.

Undang-undang ASN merupakan salah satu bentuk reformasi birokrasi dibidang kepegawaian. Harapannya dengan adanya reformasi birokrasi ini akan mengurangi beberapa permaslahan klasik mengenai birokrasi. Berdasarkan pernyataan Jenaar (2016) yang menyatakan bahwa dalam kenyataanya kondisi birokrasi Indonesia di era reformasi saat ini bisa dikatakan belum menunjukan arah perkembangan yang baik, karena masih ditemukan birokrat yang menganggap masyarakatlah yang membutuhkannya, praktik KKN yang masih banyak terjadi, dan mentalitas birokrat yang masih jauh dari harapan. Dengan beberapa permasalahan tersebut maka muncullah undang-undang ASN tersebut, dimana tujuan dari adanya undang-undang tersebut adalah untuk mengurangi permasalahan birokrasi yang ada di Indonesia. Salah satunya dalam penentuan pejabat structural eselon II, yang merupakan salah satu jabatan strategis bagi sector pemerintahan.

Promosi terbuka merupakan salah satu cara dalam reformasi birokrasi untuk memberikan peluang agar birokrasi lebih terbuka dan mendapatkan pejabat yang profesional sesuai dengan keahliannya. Namun di Indonesia beberapa daerah masih ada yang menggunakan kesempatan tersebut untuk melakukan kesalahan, seperti di salah satu daerah dimana pada pelaksanaan promosi jabatan strukutral dijelaskan bahwa Ferizal Ridwan selaku wakil Bupati Limapuluh Kota yang pada saat itu bertugas sebagai Plt Irfendi Arbi selaku Bupati yang pada saat itu sedang menunaikan ibadah Haji, ketika Ferizal Ridwan menjadi Plt tersebut beliau melakukan perubahan struktur dengan cara mutasi dan melakukan pelantikan kepada 3 (tiga) pejabat tanpa sepengetahuan Bupati dan juga tanpa adanya izin tertulis dari Kemendagri 
FisiPublik : Jurnal IImu Sosial dan Politik

https://journal.uwgm.ac.id/index.php/fisipublik

P-ISSN: 2528-2689; E-ISSN: 2540-9751

Vol 03 No 02 November 2018,

(https://news.okezone.com). Tindakan Ferizal Tersebut justru menyebabkan struktur organisasi di Dinas bahkan Setda sekalipun menjadi double karena satu jabatan masing-masing memiliki dua pejabat.

Untuk mengatasi permasalahan yang ada mengenai promosi jabatan struktural, maka pada tahun 2017 Pemerintah Kabupaten Pekalongan melakukan reformasi birokrasi dengan menjalankan proses promosi terbuka dimana promosi terbuka diharapkan mampu sebagai pengembangan karir dan mampu menempatkan ASN sesuai dengan kompetensi yang dimilikinya. Promosi terbuka di Kabupaten Pekalongan dilaksanakan pada tahun 2017 dimana promosi terbuka merupakan sistem baru dari perubahan sistem sebelumnya yang menggunakan Baperjakat. Pada tahun 2017 di Pemerintah Kabupaten Pekalongan memiliki 7 (tujuh) kekosongan formasi jabatan kepala dinas yang harus segera diisi agar tidak mengganggu pelayanan masyarakat, selain itu pengisian kekosongan formasi tersebut juga dapat memperkuat legalitas kebijakan. Dengan begitu maksud penulis dalam hal ini ingin melihat proses promosi terbuka jabatan pimpinan tinggi pratama di Kabupaten Pekalongan untuk mengetahui apakah proses promosi terbuka yang berjalan sudah sesuai dengan peraturan yang ada.

\section{Metode}

Penelitian yang berobjek pada proses promosi terbuka jabatan pimpinan tinggi pratama menggunakan pendekatan kualitatif yang bersifat deskriptif. Penelitian dalam hal ini bertujuan untuk memberi penjelasan mengenai proses promosi terbuka yang telah dilakukan pemerintah daerah Kabupaten Pekalongan pada tahun 2017. Penelitian kualitatif memiliki karakteristik sebagai berikut: (1) data penelitian diperoleh secara langsung dari lapangan, dan bukan dari laboratorium atau penelitian yang terkontrol; (2) penggalian data dilakukan secara alamiah, melakukan kunjungan pada situasi-situasi alamiah subyek; dan (3) untuk memperoleh makna baru dalam bentuk kategori-kategori jawaban, peneliti wajib mengembangkan situasi dialogis sebagai situasi ilmiah (Salim, 2006). Pengumpulan data yang dilakukan dalam penelitian yaitu melalui dokumentasi dan wawancara.

\section{Pembahasan}


FisiPublik : Jurnal IImu Sosial dan Politik

https://journal.uwgm.ac.id/index.php/fisipublik

P-ISSN: 2528-2689; E-ISSN: 2540-9751

Vol 03 No 02 November 2018,

Proses promosi terbuka jabatan pimpinan tinggi (JPT) pratama merupakan reformasi birokrasi yang dilakukan oleh pemerintah. Yang mana sebelum adanya system ini pelaksanaan promosi jabatan dilakukan oleh Baperjakat atau sering disebut dengan nama promosi tertutup. Promosi terbuka JPT merupakan langkah pemerintah dalam melakukan perubahan dimana agar sesuai dengan PP Nomor 11 Tahun 2017 agar dapat mewujudkan pejabat yang berkompeten dan berprofesional.Proses lelang jabatan atau yang disebut dengan promosi terbuka merupakan sarana awal dimana untuk mengetahui dan mengukur kemampuan seseorang dalam hal kepemimpinan.

Dimana pelaksanaan promosi terbuka akan lebih difokuskan kepada pejabat struktural eselon II. Mengingat jabatan pejabat struktural eselon II merupakan jabatan yang strategis dalam pengambilan kebijakan. Hal inilah yang menjadikan faktor bahwa pejabat struktural eselon II merupakan pejabat yang harus mempunyai komppetensi dan profesionalisme dalam bekerja. Sehingga dengan adanya kompetensi dan profesionalisme maka akan tercipta integritas yang baik bagi pejabat tersebut. Proses promosi terbuka yang diterapkan juga merupakan sebuah langkah awal, dimana sebagai upaya dalam meningkatkan kualitas sumber daya aparatur. Selain itu juga proses promosi terbuka dapat dijadikan sebagai acuan di dalam organisasi. Adapun beberapa kriteria yang bisa dijadikan acuan dalam pelaksanaan promosi terbuka di Kabupaten Pekalongan, diantaranya adalah sebagai berikut:

\section{Mekanisme Seleksi}

Mekanisme seleksi merupakan salah satu tahap yang harus diselesaikan oleh pejabat yang mengikuti promosi, mekanisme seleksi dalam hal ini dilakukan guna untuk lebih memperkuat sistem merit yang telah diatur di dalam Undang-undang Aparatur Sipil Negara. Meskipun mekanisme seleksi tidak menjamin akan memberikan hasil yang baik, namun setidaknya mekanisme seleksi merupakan langkah yang cukup selektif dalam menempatkan pejabat struktural eselon II yang memiliki kompetensi dan profesionalisme.

Dalam proses pelaksanaan promosi terbuka di Kabupaten Pekalongan ada beberapa langkah yang harus dilakukan oleh Badan Kepegawaian Daerah diantaranya adalah melakukan perencanaan, pengumuman formasi, dan seleksi. Berikut adalah alur proses promosi terbuka jabatan pimpinan tinggi prataa di Kabupaten Pekalongan tahun 2017. 
FisiPublik : Jurnal IImu Sosial dan Politik

https://journal.uwgm.ac.id/index.php/fisipublik

P-ISSN: 2528-2689; E-ISSN: 2540-9751

Vol 03 No 02 November 2018,

\section{Gambar 1}

\section{Alur Proses Promosi Terbuka Jabatan Pimpinan Tinggi Pratama di Kabupaten Pekalongan Tahun 2017}

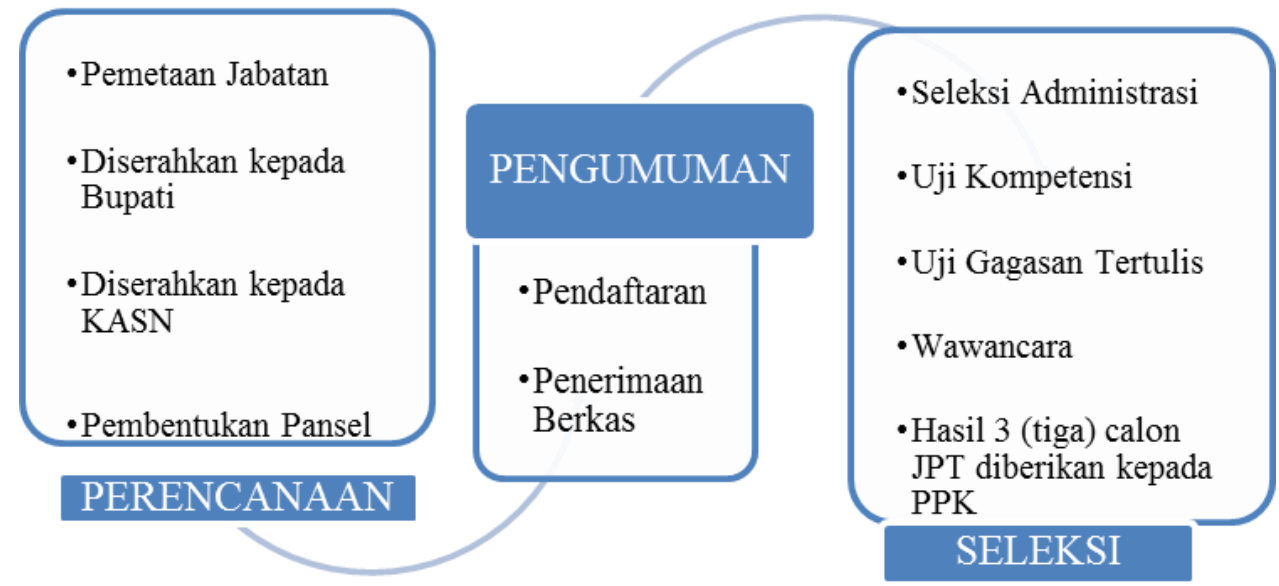

Sumber: diolah oleh peneliti tahun 2018

Berdasarkan gambar tersebut maka dapat dijelaskan mengenai pelaksanaan promosi terbuka bagi jabatan tinggi pratama di Pemerintah Kabupaten Pekalongan diantaranya adalah sebagai berikut:

Pertama perencanaan, dalam proses perencanaan ada beberapa hal yang harus dilakukan oleh Badan Kepegawaian daerah Kabupaten Pekalongan, diantaranya adalah memetakan formasi jabatan dan membentuk panitia seleksi (pansel). Berdasarkan pemetaan formasi yang dilakukan oleh Badan Kepegawaian Daerah Kabupaten Pekalongan ada beberapa formasi yang kosong. Dengan adanya kekosongan jabatan tersebut maka Badan Kepegawaian daerah mempunyai inisiatif untuk segera mengisi dengan mekanisme seleksi terbuka.

Hal tersebut merupakan metode baru dalam pengisian pejabat struktural eselon II, mengingat di dalam Undang-Undang Nomor 5 Tahun 2014 tentang Aparatur Sipil Negara pengisian jabatan pimpinan tinggi pratama dilakukan secara terbuka dan kompetitif. Maka dengan adanya Undang-Undang tersebut mekanisme yang digunakan dalam pengisian pejabat struktural eselon II menjadi promosi terbuka atau lelang jabatan. Dengan mekanisme 
FisiPublik : Jurnal IImu Sosial dan Politik

https://journal.uwgm.ac.id/index.php/fisipublik

P-ISSN: 2528-2689; E-ISSN: 2540-9751

Vol 03 No 02 November 2018,

pengisian jabatan struktural yang baru ini dapat menempatkan pegawai sesuai dengan kompetensinya atau memenuhi kaidah system merit.

Pada tahun 2017 Kabupaten Pekalongan membutuhkan 7 calon pejabat struktural baru, mengingat pada tahun tersebut ada 7 formasi yang kosong sehingga harus segera untuk diisi. Adapun tujuh formasi tersebut adalah Badan Pengelolaan Keuangan Daerah, Dinas Kearsipan dan Perpustakaan, Dinas Kelautan dan Perikanan, Dinas Komunikasi dan Informatika, Dinas PekerjaanUmum dan Penataan Ruang, Dinas Penanaman Modal PTSP dan Tenaga Kerja, Dinas Pendidikan dan Kebudayaan.

Setelah pemetaan formasi dilakukan maka Badan Kepegawaian Daerah akan memberikan kekosongan formasi tersebut kepada Bupati selaku Pejabat Pembina Kepegawaian (PPK). Dimana Pejabat Pembina Kepegawaian mempunyai kewenangan untuk memindah, atau menempatkan aparatur sipil negara (ASN). Jika Pejabat Pembina Kepegawaian tidak melakukan pemindahan atau mutasi maka kekosongan formasi tersebut akan diserahkan kepada Komisi Aparatur Sipil Negara (KASN) guna untuk mendapatkan rekomendasi pelaksanaan promosi terbuka atau lelang jabatan.

Ketika KASN mengeluarkan rekomendasi yang dikirimkan oleh daerah maka Pemerintah Daerah melalui Badan Kepegawaian Daerah bisa membentuk Panitia Seleksi (Pansel). Pembentukan Pansel ini berdasarkan ketentuan Peraturan Pemerintah No 11 tahun 2016 Pasal 114 yang terdiri dari unsur dan syarat sebagai berikut: 1) "Pejabat pimpinan tinggi terkait dari lingkungan Instansi Pemerintah yang bersangkutan, 2) Pejabat pimpinan tinggi dari Instansi Pemerintah lain yang terkait dengan bidang tugaas Jabatan yang lowong, 3) Akademisi, pakar atau profesional, 4) Memiliki pengetahuan dan/atau pengalaman sesuai dengan jenis, bidang tugas, dan kompetensi Jabatan yang lowong, 5) Memiliki pengetahuan umum mengenai penilaian kompetensi, 6) Tidak menjadi anggota/ pengurus partai politik, dan 7) tidak berpotensi menimbulkan konflik kepentingan.

Berdasarkan kriteria tersebut pemerintah daerah Kabupaten Pekalongan memebentuk pansel yang berjumlahkan 5 anggota. Adapun kelima anggota pansel terdiri dari empat unsur akademisi dan satu unsur pakar. Dengan terbentuknya pansel maka kewenangan untuk menyelenggarakan proses promosi terbuka diserahkan kepada pansel. Sehingga pelaksanaan promosi terbuka di Kabupaten Pekalongan dilakukan oleh pansel sepenuhnya. 
FisiPublik : Jurnal IImu Sosial dan Politik

https://journal.uwgm.ac.id/index.php/fisipublik

P-ISSN: 2528-2689; E-ISSN: 2540-9751

Vol 03 No 02 November 2018,

Kedua Pengumuman, pelaksanaan pengumuman formasi jabatan bisa dilakukan setelah panitia seleksi terbentuk. Pengumuman formasi jabatan harus disebar luaskan kepada klayakan umum demi terjaringnya aparatur yang mempunyai kompetensi dan profesional. Prinsip dari pelaksanaan promosi terbuka adalah seluruh aparatur sipil negera mempunyai kesempatan yang sama untuk menduduki jabatan tersebut, jadi tidak terbatas ASN yang berada di Kabupaten Pekalongan atau Jawa tengah saja. Dengan adanya pengumuman tersebut maka akan terjadi kompetisi sehingga pejabat struktural yang didapat merupakan pejabat yang mempunyai kompetensi dan profesional.

Ketiga Seleksi, dalam pelaksanaan seleksi ada beberapa tahap yang harus dilalui oleh calon pejabat struktural diantaranya adalah seleksi administrasi, seleksi manajerial dan seleksi bidang. Mekanisme seleksi dilakukan oleh Panitia Seleksi (Pansel) dimana pansel itu sendiri sudah dibentuk sejak awal proses promosi terbuka pada bagian perencanaan, dan pansel di Kabupaten Pekalongan terdiri dari lima anggota dengan kategori dari empat unsur akademisi dan satu unsur pakar yang semuanya menguasai bidang kepegawaian.

Selain itu ada beberapa kriteria penilaian pada pelaksanaan proses promosi terbuka jabatan tinggi pratama di lingkungan Pemerintah Kabupaten Pekalongan, diantaranya adalah sebagai berikut:

a. Penilaian Kompetensi manajerial

Setelah pejabat lolos pada tahap seleksi administrasi maka langkah selanjutnya yang harus dilakukan yaitu mengikuti assesment center, dimana assesment center dalam hal ini yaitu untuk mengukur nilai dalam hal manajerial dari masing-masing pejabat. Assesment center itu sendiri dilakukan oleh pihak ketiga yaitu melalui Badan Kepegawaian Daerah Provinsi.

\section{b. Penilaian Kompetensi Bidang}

Seleksi lain yang harus dilaksanakan oleh calon pejabat struktural eselon II adalah melakukan uji tertulis, uji wawancara dan rekam jejak. Dalam pelaksanaan uji tertulis peserta harus membuat makalah, yang mana makalah tersebut harus dipersentasikan di depan panitia seleksi. Dengan adanya persentasi tersebut maka akan sangat membantu panitia seleksi dalam melakukan penilaian, sehingga hal ini juga menjadikan salah satu 
FisiPublik : Jurnal IImu Sosial dan Politik

https://journal.uwgm.ac.id/index.php/fisipublik

P-ISSN: 2528-2689; E-ISSN: 2540-9751

Vol 03 No 02 November 2018,

indikator untuk menunjukkan kompetensi calon pejabat struktural eselon II tersebut. Selain itu ada beberapa tes lagi diantaranya adalah uji wawancara dan rekam jejak, dengan adanya hal tersebut maka panitia seleksi mempunyai keleluasaan untuk memberikan penilaian dan menetapkan calon pejabat struktural eselon II.

Penilaian terhadap rekam jejak merupakan hal yang sangat bagus, karena dengan adanya penilaian rekam jejak tersebut maka bisa dijadikan sebagai bahan rekomendasi panitia seleksi dalam menentukan skor penilaian. Rekam jejak itu sendiri dianggap sebagai acuan dalam proses penilaian dimana metode yang dilakukan Pemerintah Kabupaten yaitu dengan melakukan verifiksi berkas lamaran dan juga hunting langsung ke OPD pelamar tanpa memberi pengetahuan sebelumnya. Hunting tersebut berguna untuk menanyakan langsung hal-hal yang diperlukan.

Dengan adanya penilaian yang sudah dilakukan tadi maka aka nada penggabungan nilai yang menggunakan metode penilaian kualitatif dan juga penilaian kuantitatif. Penilaian tersebut akan menghasilkan tiga poin diantaranya: memenuhi syarat, tidak memenuhi syarat dan kurang memenuhi syarat. Dari ketiga poin tersebut yang nantinya akan menjadi bahan pertimbangan untuk menentukan skor. Penentuan skor itu sendiri menggunakan penilaian kuantitatif yang berupa poin untuk melaporkan hasil akhir seleksi dan laporan tersebut akan diajukan masing-masing formasi terdapat tiga calon nama yang akan diserahkan kepada Pejabat Pembina Kepegawaian (PPK).

\section{Pengalaman}

Pengalaman merupakan salah satu faktor utama dalam pelaksanaan promosi terbuka di Kabupaten Pekalongan tahun 2017. Dimana pejabat yang mengikuti promosi untuk mengisikekosongan formasi harus memiliki pengalaman yang layak dan sesuai untuk menduduki jabatan sebagai JPT. Pengalaman tersebut dapat dilihat dari pengalaman bekerja yang sudah mencapai minimal 5 (lima) tahun dibidangnya. Prosedur yang dilakukan Pemerintah Kabupaten Pekalongan itu sendiri sudah sesuai dengan PP Nomor 11 Tahun 2017 tentang Manajemen PNS pada pasal 107 yang menjelaskan mengenai persyaratan pejabat yang akan mengikuti promosi JPT Pratama. 
FisiPublik : Jurnal IImu Sosial dan Politik

https://journal.uwgm.ac.id/index.php/fisipublik

P-ISSN: 2528-2689; E-ISSN: 2540-9751

Vol 03 No 02 November 2018,

Keahlian dan jenjang karir juga merupakan salah satu hal yang dijadikan acuan untuk penilaian didalam proses promosi terbuka, penilaian prestasi kerja itu sendiri dapat dilihat berdasarkan penilaian SKP dari setiap calon untuk melihat apakah pejabat dapat mencapai target pekerjaan yang telah ditentukan. Pengukuran loyalitas itu sendiri juga dilihat dari segi hukuman itu sendiri, dimana ketika pejabat tidak pernah diberikan hukuman mulai dari tingkat rendah sampai dengan tingkat yang berat maka pejabat tersebut dianggap telah mampu menjalankan tugasnya dengan baik. Selain prestasi kerja ada beberapa hal yang perlu diperhatikan diantaranya adalah minimal eselon bagi pegawai yang ingin mendaftarkan diri sebagai pejabat struktural eselon II. Dimana untuk calon pejabat struktral eselon II harus mempunyai minimalnya bereselon II dan sudah memiliki golongan IVa.

\section{Kesimpulan}

Proses promosi terbuka JPT yang dilakukan Pemkab Pekalongan sudah berjalan dengan baik, lancar dan normatif. Selain itu proses tersebut juga sudah dilakukan sesuai dengan peraturan yang ada. Dimana dalam pelaksanaan proses promosi terbuka di Kabupaten Pekalongan secara garis besar akan dilakukan penilaian melalui 2 hal yaitu mekanisme seleksi dan pengalaman. Untuk mekanisme seleksi sendiri masih dibagi beberapa tahap yang harus dilalui diantaranya adalah adanya perencanaan, pengumuman dan seleksi. Dengan adanya beberapa tahap tersebut maka sangat membantu panitia seleksi dalammenentukan pejabat yang mempunyai kompetensi dan profesional. Sedangakan untuk pengalaman merupakan hal yang paling penting dan harus ada. Kriteria untuk minimal calon pejabat strukutal memiliki pengalaman adalah 5 tahun, dengan adanya pengalaman tersebut maka sangat membantu panitia seleksi untuk menilai kompetensi calon pejabat struktural. Selain menjadi syarat penilaian pengalaman juga merupakan salah satu komponen yang sangat penting untuk membantu pejabat struktural dalam mengelola organisasi yang akan dipimpin. Mengingat pengalaman merupakan hal yang sangat penting dan mendukung kepemimpinan seseorang, sehingga hal yang wajar jika pengalaman juga dijadikan sebagai indikator penilaian bagi calon pejabat struktural di Kabupaten Pekalongan pada proses promosi terbuka tahun 2017. 
FisiPublik : Jurnal IImu Sosial dan Politik

https://journal.uwgm.ac.id/index.php/fisipublik

P-ISSN: 2528-2689; E-ISSN: 2540-9751

Vol 03 No 02 November 2018,

\section{Daftar Pustaka}

Atmojo,Muhammad Eko. 2016. Analisis Proses Promosi Jabatan Aparatur Sipil Negara Studi Kasus: Proses Promosi Jabatan Struktural Eselon II di Pemerintah Daerah Istimewa Yogyakarta Tahun 2014. Jurnal Aristo. Vol 4. No 2.

Jennar, Mahezha. (2016). Manajemen Kepegawaian Dalam Meningkatkan Kinerja Aparatur Sipil Di Sekretariat Daerah Provinsi Kalimantan Timur. Jurnal Paradigma, Vol. 5 No.1, April.

Salim, A. (2006). Teori dan Paradigma Penelitian Sosial: Buku Sumber untuk Penelitian Kualitatif edisi kedua. Yogyakarta: Tiara Wacana.

Undang-Undang No 5 Tahun 2014 tentang Aparatur Sipil Negara

Peraturan Pemerintah Nomor 11 Tahun 2017 tentang Manajemen Pegawai Negeri Sipil

Nasution. M. Syarif. (2013). Lelang Jabatan Dalam Perspektif Kebijakan publik. http://sumut.kemenag.go.id (diakses pada tanggal 10 Oktober 2018)

Okezone News. 2017. Wabup di Sumbar Mutasi Pejabat saat Bupati Naik Haji, Kemendagri: ini kasus pertama di Indonesia. https://news.okezone.com (diakses pada tanggal 7 Oktober 2018) 